Journal of Life Economics

Cilt / Volume 7, Say1 / Issue 3, 2020, pp. 269-282

E - ISSN: 2148-4139

URL: https://www.journals.gen.tr/jlecon

DOİ: https://doi.org/10.15637/jlecon.7.020

Araştırma Makalesi/Research Article

\title{
COINTEGRATION EVIDENCES FROM THE NEW FRAGILE FIVE
}

\author{
Gülgün ÇİĞDEM* \& Merve ALTAYLAR** \\ * Istanbul Gelişim University, TURKEY \\ e-mail: gulguncigdem@gmail.com \\ ORCID: https://orcid.org/0000-0001-5353-8638 \\ ** Dokuz Eylül University, TURKEY \\ e-mail: mervealtaylar37@gmail.com \\ ORCID: https://orcid.org/0000-0001-5413-5048
}

Received: 1 July 2020; Accepted: 26 July 2020

\begin{abstract}
Purpose of this study is to test the association between savings and current account deficit of the "New Fragile Five" falling into critical cycle. 1994-2019 period annual national savings, current account balance and external debt have been analyzed within the framework of panel data analysis. At the modeling stage of the research focused on the cointegration relationship. Panel cointegration tests with structural breaks based on LM were used. To examine the unique economic structures of countries, heterogeneous estimating techniques were employed. The research has four important findings; i.There is a cointegration relationship between indicators, ii.The external debt increases the current account deficit, iii.The increase of savings in Turkey decreases the current account deficit, iv.An increase in savings increases the current account deficit in Argentina, Egypt, Pakistan and Qatar. This study, which will contribute to the expansion of typology, is also contributory to the "Triple Deficit Hypothesis".
\end{abstract}

Keywords: Current Account Deficit, Savings, Triple Deficit, Heterogeneous Panel, Cointegration with Structural Breaks, Unit Root with Structural Breaks

Jel Codes: E21, F32, E42, C33, C52 


\section{INTRODUCTION}

For the first time in 2013, Morgan Stanley used the concept of fragility in order to refer to economies becoming fragile due to high current account deficits (CAD) and their dependence on global capital flows, and created the "Fragile Five". Afterward, the "Fragile Eight" group was created. And in 2017, "New Fragile Five" group was created by Standard \& Poor's (S\&P). Common ground of these countries is; balance of payments disequilibrium, finance of which becomes more and more challenging, and the rising high borrowing need. Due to their dependence on international capital flows, these economies become fragile against foreign shocks. CAD is -if certain threshold values are exceeded- accepted as significant crisis indicators. The main symptom behind the CAD problem is; insufficiency of national savings (Çiğdem, 2017; Çiğdem and Ülgen, 2017). Researchers stated in Table 1 has also confirmed that savings are among the determinants of CAD. So that a decrease in savings-investment deficit contributes to improvement of CAD (Chowdhury and Saleh, 2007).

Table 1. Researchers

\begin{tabular}{llll}
\hline Researcher & Year & Researcher & Year \\
\hline Obstfeld and Rogoff & 1994 & Choi et al. & 2008 \\
Calderon et al. & 2001 & Ketenci and Uz & 2009 \\
Calderon et al. & 2002 & Ketenci & 2010 \\
Taylor & 2002 & Brissimis et al. & 2010 \\
Herrman and Jochem & 2005 & Brissimis et al. & 2011 \\
Aristovnik & 2006 & Liang & 2012 \\
Engel and Rogers & 2006 & Murty et al. & 2013 \\
\hline
\end{tabular}

Existence, and in particular, direction of a relationship between CAD and savings have been one of the most debated subjects. Empirical studies carried out have produced different results, for example; Barış and Uzay (2015) determined a strong causality relationship from CAD to savings while Kaygisiz et al. (2016) indicated a one-way relationship from savings to CAD. On the other hand, Karanfil (2014) and Altunöz (2018) found a two-way causality relationship between variables. Çiğdem and Ülgen (2017) pointed out a two-way relationship between variables in Brazil, South Africa and India, a one-way relationship from CAD to savings in Chile and Poland, and a one-way relationship from savings to CAD in Indonesia. No relationship between variables has been determined in Hungary and Turkey. In these countries with fragile structures, determining the existence and direction of a relationship between variables is of importance especially for policymakers. This study is contributory to the literature due to limited number of studies on the New Fragile Five and even the Triple Deficit.

\section{METHODOLOGY, DATA AND EMPIRICAL RESULTS}

In this section, where the savings-CAD relationship will be analyzed, the 1994-2019 period annual data obtained from IMF have been tested. GDP and investment data were also analyzed as auxiliary variables. Stata 14.0 and Gauss 10 software has been used from during econometric analyses. An analysis within the panel cointegration model has been carried out in order that reciprocal synchronous long-run relationships among the examined variables can be demonstrated. Heterogeneous estimation techniques are of particular importance. Because, while providing an overview about the Fragile Five, the unique economic structures of the countries can be observed. Several estimators which have different theoretical basis were used to estimate the panel regression model. Regression have been estimated for a more detailed analysis of the relationship between variables.

Within this context, both the relationship between variables during analysis and the effect of changes in the variables on the same variables have been observed. Table 2 indicates the variables used in the analyses. 
Table 2. Variables

\begin{tabular}{lccc}
\hline Variables & Code & Units & Source \\
\hline Current Account Deficit & CAD & $\%$ GDP & IMF \\
National Savings & S & $\%$ GDP & IMF \\
External Debt & ED & $\%$ GDP & IMF \\
Gross Domestic Product & GDP & $\%$ Growth & IMF \\
Investment & I & $\%$ GDP & IMF \\
\hline
\end{tabular}

\subsection{Panel Unit Root Tests}

Before proceeding to the estimation phase of the regression model time series properties of macroeconomic variables were investigated. Panel unit root tests are divided into two within the literature that so-called first-generation panel unit root tests assuming there is no crosssectional dependence. The so-called second-generation panel unit root tests run on the assumption of cross-sectional dependence. The main advantage of second-generation tests over other tests is that they allow cross-sectional correlation (Güloğlu et al. 2012:606). As argued by O'Connell (1998), possible correlations between cross-section series can lead to overreject of the null hypothesis of first generation tests. Whether there is cross-sectional dependency in variables must be tested before the selection of panel unit root test, and a panel unit root test must be selected accordingly. For this purpose, weak cross-sectional dependence $\mathrm{CD}_{\mathrm{NT}}(\mathrm{N}<10)$ test developed by Pesaran (2015) and bias adjusted LM test (LMadj.) developed by Pesaran et al. (2008) were used.

For this purpose, three panel unit root tests were used: CIPS test developed by Pesaran (2007); MADF test developed by Taylor and Sarno (1998) and PANKPSS test developed by Carrion-i Silvestre et al. (2005) for testing unit roots in the variables.

Pesaran (2007), augmented the ADF regression through cross-section average and lagged values of series, and developed the cross-sectionally augmented IPS, namely the CIPS statistics, asserting that correlation between cross-sections had been eliminated through firstorder difference of such regression. Null hypothesis of the test is formed as $H_{0}: \rho_{i}=0$ (for each i). CIPS statistics is calculated as:

$$
\operatorname{CIPS}(N, T)=N^{-1} \sum_{t=1}^{N} t_{i}(N, T)
$$

and truncated version of this statistics is;

$$
\operatorname{CIPS}^{*}(N, T)=N^{-1} \sum_{i=1}^{N} t_{i}^{*}(N, T)
$$

Pesaran (2007) stated the powerful part of this test to be good small sample properties (Pesaran, 2007:277).

Taylor and Sarno (1998) propose the multivariate augmented Dickey-Fuller (MADF) unit root test, which is similar to the classic single equation ADF test. In the model which proposed a system with $\mathrm{N}$ equation is estimated and a test process is applied by considering the correlation between the cross sections. MADF statistics is actually standard Wald statistics and is shown as below:

$$
M A D F=\frac{(l-\varphi \widehat{\beta})\left\{\varphi\left[Z \prime\left(\hat{\Lambda}^{-1} \otimes I_{T}\right) Z\right]^{-1} \varphi^{\prime}\right\}(l-\varphi \widehat{\beta}) N(T-k-1)}{(Y-Z \widehat{\beta})^{\prime}\left(\hat{\Lambda}^{-1} \otimes I_{T}\right)(Y-Z \widehat{\beta})}
$$

Where, $\varphi$ represents dimensional with $N x N(k+1)$ block diagonal matrix and I vector with $N x l$ dimensional. $\widehat{\boldsymbol{\beta}}$ and $\hat{\Lambda}$ represent consistent estimators of $\beta$ and $\Lambda$. The null hypothesis of this test indicates that there is no unit root in the series (Taylor and Sarno, 1998:288). The 
theoretical base of the panel unit root test proposed by Carrion-i Silvestre et al. (2005) are different and structural breaks are taken into account. Under the assumption that the long-run variance is constant (by groups), using the $\mathrm{LM}_{\text {hom }}$ statistic, the null hypothesis of stationarity is tested as follows:

$$
L M_{h o m}(\lambda)=N^{-1} \sum_{i=1}^{N}\left(\widehat{\omega}^{-2} T^{-2} \sum_{t=1}^{T} S_{i, t}^{2}\right)
$$

Where, $S_{i t}=\sum_{j=1}^{t} u_{i j}$ and $N^{-1} \sum_{i=1}^{N} \widehat{\omega}_{i}^{2}=\lim _{t \rightarrow \infty} T^{-1} S_{i, T}^{2}$. When the long-run variance is allowed to change according to the groups, $\mathbf{L M}_{\text {het }}$ statistics are used and shown as follows:

$$
L M_{h e t}(\lambda)=N^{-1} \sum_{i=1}^{N}\left(\widehat{\omega}_{i}^{-2} T^{-2} \sum_{t=1}^{T} S_{i, t}^{2}\right)
$$

In these equations $(4,5), \hat{u}_{i j}$ refers to OLS residuals, and $\omega_{i}^{2}$ is the long-run variance of $u_{i j}$. LM statistics are standardized as follows:

$$
Z(\lambda)=\frac{\sqrt{N}(L M(\lambda)-\bar{\xi}}{\bar{\zeta}} \sim N(0,1)
$$

In this equation (6), $\xi^{-}$and $\zeta^{-}$are the average of the mean and variance for each cross section, respectively. Also, structural breaks are allowed to change according to the series (Carrion-i Silvestre et al., 2005: 161-163).

\subsection{Panel Cointegration Test}

Cointegration refers to a very special relationship structure that can be defined as a longrun synchronous movement between variables. In this study, the relationship between the "CAD-Savings-ED" in the Fragile Five was investigated by LM based panel cointegration tests. These tests are LM based cointegration tests developed by Westerlund (2006) and Westerlund \& Edgerton (2008) that take into account structural breaks. The main advantages of these tests are that it allows cross-sectional dependence and heterogeneous slopes.

In panel LM test with multiple structural breaks developed by Westerlund (2006), breaks are determined endogenously. In other words, the breaks date is not known before. In this test, cross-sectional dependence and heterogeneous slopes are allowed, as well as different number of breaks and different break dates according to the groups. The model for this test is shown below:

$$
\begin{aligned}
& y_{i t}=z^{\prime}{ }_{i t} \gamma_{i j}+x_{i t}^{\prime} \beta_{i}+e_{i t} \\
& e_{i t}=r_{i t}+u_{i t} \\
& r_{i t}=r_{i t-1}+\emptyset_{i} u_{i t}
\end{aligned}
$$

Where, $x_{i t}=x_{i t-1}+v_{i t}$. The statistics of the test are as follows:

$$
Z(M)=\sum_{i=1}^{N} \sum_{j=1}^{\mu_{i}+1} \sum_{t=T_{i j-1}+1}^{T_{i j}}\left(T_{i j-} T_{i j-1}\right)^{-2} \widehat{\omega}_{i 1.2}^{-2} S_{i t}^{2}
$$

The null hypothesis of this test indicates the presence of cointegration. In equation 10 $\widehat{\omega}_{i 1.2}^{2}=\widehat{\omega}_{i 11}^{2}-\widehat{\omega}_{i 21}^{\prime} \hat{\Omega}_{i 22}^{-1} \widehat{\omega}_{i 21}$ and $S_{i t}=\sum_{k=T_{i j-1}}^{t} \hat{e}_{i k}^{*}$. Where, $\hat{e}_{i t}^{*}$ is an efficient estimator of $e_{i t}$ (Westerlund, 2006:103-104). 
Another cointegration test used in the research is an LM based test developed by Westerlund and Edgerton (2008), which have a structural breaks assumption.This test also allows for serially correlated and heteroscedastic residuals, breaks in both constant and slope. LM cointegration test by suggested Westerlund and Edgerton (2008) can be which can simply be written as follows (Westerlund and Edgerton, 2008);

$$
\begin{aligned}
& \varphi_{N}=\frac{1}{N} \sum_{i=1}^{N} T \hat{\varphi}_{i} S_{i} \\
& \tau_{N}=\frac{1}{N} \sum_{i=1}^{N} \tau_{i}
\end{aligned}
$$

$S_{i}=\widehat{\omega}_{i} / \hat{\sigma}_{i}$ where $\hat{\sigma}_{i}$ is estimated regression ${ }^{1}$, standard error $\hat{\varphi}_{i}$ is the OLS estimate of $\varphi_{i}$ and $\tau_{i}$ its t-ratio. The null hypothesis of this test is that there is no cointegration relationship. As argued by Westerlund and Edgerton (2008) that this test has good performance in small samples.

\subsection{Panel Regression Estimators}

Slope heterogeneity should be tested before estimating a panel regression model. This term means that each cross section has its own slope, which is statistically significant. As argued by Maddala, Trost, Li and Joutz (1997), if panels with heterogeneous slopes are estimated by the assumption of homogeneity, then heterogeneity bias may occur. Homogeneous slopes were investigated with the $\dot{\hat{S}}$ test developed by Swamy (1970) and the slope homogeneity test developed by Pesaran and Yamagata (2008). Swamy $\dot{\hat{S}}$ test is for panels where cross-sectional dimension $(\mathrm{N})$ is small relative to time dimension $(\mathrm{T})$. The $\tilde{\Delta}$ test is for large panels (Pesaran and Yamagata, 2008:209). Therefore, were employed the bias adjusted version of this test $\left(\tilde{\Delta}_{a d j}\right)$ in the research.

In this study, advanced panel data analysis techniques have been applied where the characteristics of the groups such as individuals, countries and the correlation between crosssections are not ignored. It is very important to provide information on the basis of groups as well as providing information about the overall panel. Thus, groups that are compatible with the results of the panel can also be identified. For this purpose, AMG estimator developed by Eberhardt and Teal (2010) and Eberhardt and Bond (2009); CCE estimator developed by Pesaran (2015); SUR estimator developed by Zellner (1962) and panel DOLS estimator developed by Pedroni (2001) was used. The values obtained for each group are combined with the MG approach developed by Pesaran and Smith (1995) (Eberhardt and Bond 2009:2-3). The theoretical details of the panel regression estimators used in the study are given respectively.

The panel regression model by AMG estimator can be expressed as follows:

$$
y_{i t}=a_{i}+b_{i}^{\prime} x_{i t}+c_{i t}+d_{i} \hat{\mu}_{t}+e_{i t}
$$
variable.

Where " $\mu_{i}$ " unobserved common factors, $x_{i t}$ is explanatory variables and y is dependent

At the last stage, the following model is estimated:

$\hat{\beta}_{A M G}=N^{-1} \sum_{i=1} \hat{\beta}_{i}$

The CCE estimator is based on a linear model such as:

$$
y_{i t}=a_{i}^{\prime} d_{t}+b_{i}^{\prime} x_{i t}+e_{i t} i=1, \ldots, N \quad t=1, \ldots, T
$$


Then each group is averaged and combined with the MG approach:

$$
\hat{\beta}_{C C E M G}=N^{-1} \sum_{i=1} \hat{\beta}_{i}
$$

Where $\beta i$ represents to the slope specific to each cross section (Pesaran, 2006: 982). Pesaran (2006) stated that the CCE estimator is more suitable for heterogeneous large panels, but later Monte Carlo experiments by Kapetanios, Pesaran and Yamagata (2011) showed that the CCE estimator is better in small samples than the alternative estimators in the literature (Pesaran 2006; Kapetanios et al.2011).

Another estimator included in the paper is the DOLS, which is frequently used in the estimation of cointegration relations. The DOLS estimator also includes preliminary and lagged values of arguments. Thus, it also ensures the destruction of endogeneity. A regression model with slope heterogeneity is based on:

$$
y_{i t}=\mu_{i}+\beta_{i} x_{i t}+u_{i t} i=1, \ldots, N \quad t=1, \ldots, T
$$

Then the results are combined for the panel;

$$
\hat{\beta}_{D O L S M G}=N^{-1}\left[\sum_{i=1}^{N}\left(\sum_{t=1}^{T}\left(Z_{i t} Z_{i t}^{\prime}\right)^{-1}\right]\left(\sum_{t=1}^{T}\left(Z_{i t} \bar{Y}_{i t}\right)\right)\right.
$$

Where $Z_{i t}$ is column vector of explanatory variables and $\mathrm{y}$ is dependent variable (Pedroni, 2001:729).

SUR estimator is different from other methods. In SUR method, the system can be solved as a whole and loss of effectiveness can be prevented. In addition, the correlation between regression and residuals of models is also taken into account. Where in this method, first, each group is estimated individually as follows:

$$
Y_{i}=X_{i} \beta_{i}+u_{i}
$$

and omega matrix is calculated,

$$
\hat{\beta}=\left(X^{\prime} \Omega^{-1} X\right)^{-1} X^{\prime} \Omega^{-1} Y
$$

Where, $\Omega$ represents the variance-covariance matrix, $y$ is a dependent variable and $x_{i t}$ explanatory variable. Then, regression model is estimated by GLS (Zellner, 1962: 340).

In this research, 1994-2019 period annual CAD, S, ED, INV and GDP data of five countries named the New Fragile Five (Argentina, Egypt, Qatar, Pakistan and Turkey) are examined. Panel regression model to be estimated within the scope of the research is shown as the following:

$$
C A D_{i t}=a_{i}+\beta_{1 i} S_{i t}+\beta_{2 i} E D_{i t}+u_{i t}
$$

Table 3. Descriptive Statistics

\begin{tabular}{lcccccc}
\hline Variables & Obs. $(N x T / 25 x 5)$ & Mean & Median & St. Dev. & Min. & Max. \\
\hline CAD & 125 & 0.394152 & -1.355 & 9.560282 & -27.25 & 33.185 \\
S & 125 & 24.00102 & 20.218 & 13.82498 & 9.076 & 64.189 \\
ED & 125 & 2.982566 & -2.139 & 14.12176 & -13.489 & 47.199 \\
GDP & 125 & 4.966409 & 4.674 & 5.436894 & -10.895 & 30.012 \\
INV & 125 & 22.75357 & 19.32 & 8.145491 & 10.306 & 46.674 \\
\hline
\end{tabular}


Descriptive statistics for variables are presented in Table 3 before estimating the model. Furthermore, it is seen that the data set displays balanced and long panel characteristics. It is also very important that the median of the CAD and ED variables are negative. This situation is actually an indication that there is a CAD and external debt in the fragile five.

Table 4 : Cross-section Dependence Tests (for variables)

\begin{tabular}{lcc}
\hline Variables & Bias Adj. CD St. $\left(\mathrm{CD}_{\mathrm{adj}}\right)$ & Pesaran $(2015) \mathrm{CD}_{\mathrm{NT}}$ St. \\
\hline $\mathrm{CAD}$ & $45.717^{*}$ & $3.742^{*}$ \\
$\mathrm{~S}$ & $45.717^{*}$ & $1.878^{* * * *}$ \\
$\mathrm{ED}$ & $45.717^{*}$ & $2.131^{* *}$ \\
\hline
\end{tabular}

Note: ***,*** denote the significance levels of alpha at $0.01,0.05$, and 0.10 respectively.

Findings for the cross-sectional dependence are illustrated in Table 4. According to this table, is rejected the null hypotheses of absence of cross section dependence by looking at the results of $\mathrm{CD}_{\mathrm{NT}}$ test and $\mathrm{LM}_{\mathrm{adj}}$ tests. Thus, it was observed that there is problem of crosssectional dependence. Therefore, before proceeding with the unit root analyses, secondgeneration panel unit root tests functioning under the presence of cross-sectional dependence must be selected. In this research, presence of unit root has been tested using the CIPS, MADF and PANKPSS (with structural breaks) panel unit root tests.

Table 5 : Panel Unit Root Tests

\begin{tabular}{lllccc}
\hline & \multicolumn{2}{c}{ CIPS } & MADF & \multicolumn{2}{c}{ PANKPSS } \\
\hline Variables & t-bar St. Intercept & t-bar St. Int\&Trend & MADF St. Intercept & LM St. Intercept & LM St. Int\&Trend \\
\hline CAD & -0.575 & -0.952 & 20.448 & $1.527^{* * *}$ & $39.478^{*}$ \\
S & -0.281 & -0.199 & 18.948 & $4.681^{*}$ & $27.410^{*}$ \\
ED & -0.681 & -1.150 & 30.353 & -0.055 & $16.458^{*}$ \\
$\Delta$ CAD & $-5.077^{*}$ & $-3.437^{*}$ & 117.411 & & \\
$\Delta \mathrm{S}$ & $-2.740^{*}$ & $-1.629^{* *}$ & 146.478 & & \\
$\Delta \mathrm{ED}$ & $-5.018^{*}$ & $-3.365^{*}$ & 136.176 & & \\
\hline
\end{tabular}

Note :i. *,***** denote the significance levels of alpha at $0.01,0.05$, and 0.10 respectively. ii.Critical values for the MADF test are 31.844 (level) and 33.168 (first dif.).

Table 5 shows the results of the panel unit root tests with different theoretical basis. According to CIPS and MADF test statistics, the null hypothesis indicating the unit root existence can not be rejected. The results of CIPS and MADF test stat. are also supported by the result of PANKPSS test. The results of the panel unit root tests where the breaks are not taken into account and are taken are in consistency. Moreover, the results of the PANKPSS test showed that the factors affecting the stationary of variables are not only structural breaks.

Table 6 : Slope Homogeneity and CSD Test

\begin{tabular}{lcc}
\hline Swamy Slope Het. Test $\chi^{2}$ St. & Pesaran\&Yamagata $\tilde{\Delta}$ St. & Pesaran\&Yamagata $\tilde{\Delta}_{\text {adj. St. }}$ \\
\hline $119.3632^{*}$ & $7.2769^{*}$ & $8.0970^{*}$ \\
\hline Cross-section Dependence Tests (for model) & \\
\hline Bias Adj. CD Test St. & Breusch-Pagan LM St. & Breusch-Pagan LMadj. St. \\
\hline $6.399^{*}$ & $17.25^{* * *}$ & $3.974^{*}$ \\
\hline Note: $* * *, * * *$ denote the significance levels of alpha at $0.01,0.05$, and 0.10 respectively.
\end{tabular}

Table 6 shows the tests (slope homogeneity and CSD) applied for the model. It has been concluded that the null hypothesis stating that slopes are homogeneous was rejected (at different levels of significance). According to the CSD tests, there is a CSD problem in the model. Therefore, these two assumptions should be considered in the selection of both the panel cointegration test and the panel regression estimator. This situation turns the direction of analysis into second generation panel cointegration tests and regression estimators. 
Table 7. Panel Cointegration Tests

\begin{tabular}{lccc}
\hline \multicolumn{2}{c}{ Westerlund (2006) } & \multicolumn{2}{c}{ Westerlund\&Edgerton (2008) } \\
\hline LM St. (Cons.) & LM St. (Cons.\&Trend) & Tau St. $(\tau)$ & Phi St. $(\varphi)$ \\
\hline 28.559 & 0.401 & $-3.519^{*}$ & $-2.495^{*}$ \\
\hline Note: $* * *, * * *$ \\
\end{tabular}

Table 7 shows the results of the panel cointegration tests with the structural breaks. Tau, phi and LM statistics indicate cointegration. In other words, these variables show a synchronous relationship in the long-run. Therefore the level values of the variables can be used for the rest of the analysis. Figure 1 shows the graphs of macroeconomic variables of the New Fragile Five. Synchronous mobility between variables is clearly noticeable.

Figure 1. Graphics by Groups ${ }^{2}$

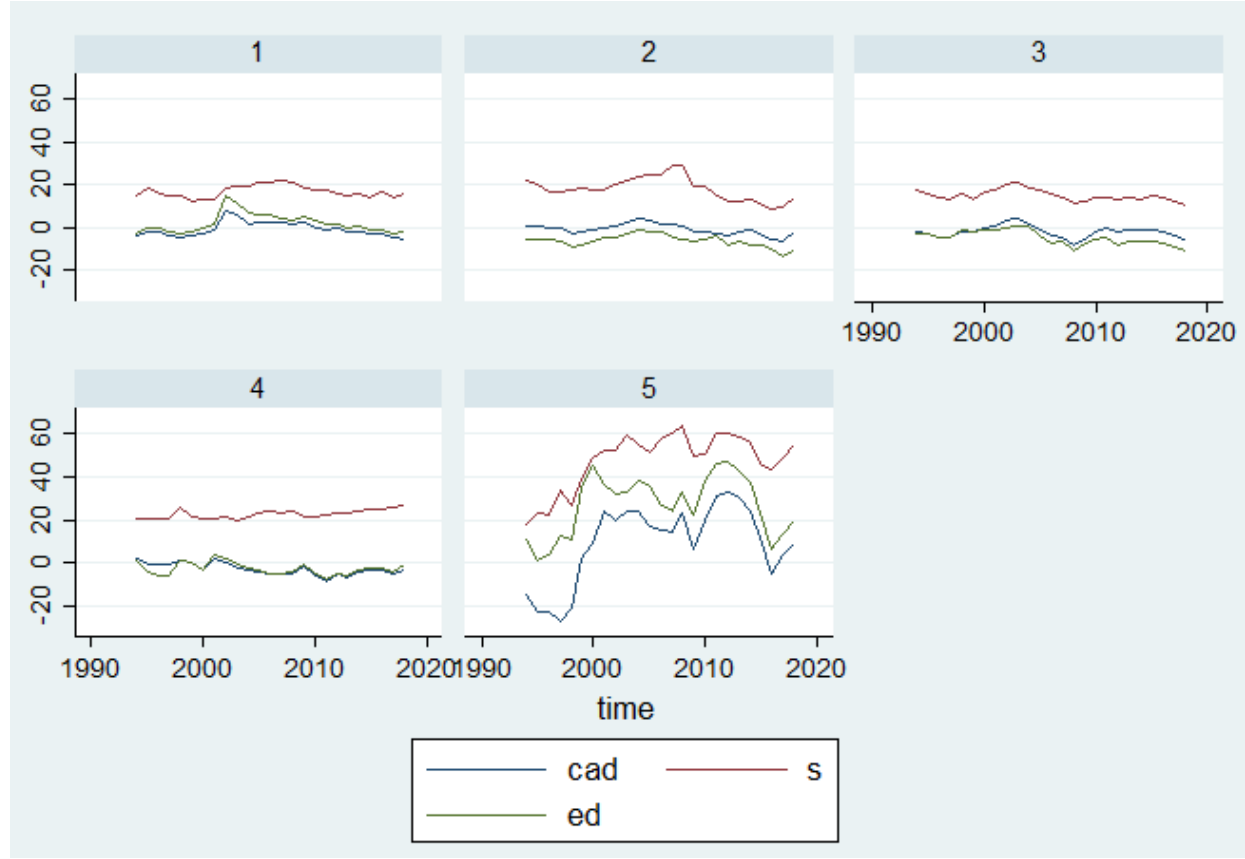

Table 8. Estimation Results (by panel)

\begin{tabular}{|c|c|c|c|c|}
\hline \multicolumn{5}{|c|}{ Dependent Variables: CAD } \\
\hline Regressors & CCE (robust) & AMG (robust) & DOLS & SUR \\
\hline $\mathrm{S}$ & $0.2352[2.44]^{* *}$ & $0.2463 \quad[1.44]$ & 0.4446 [6.793]* & $0.2362 \quad[4.54]^{*}$ \\
\hline ED & $0.5960[6.04]^{*}$ & $0.5873[10.81]^{*}$ & $1.433[18.13]^{*}$ & $0.5332[12.43]^{*}$ \\
\hline \multicolumn{5}{|l|}{ Model } \\
\hline RMSE & 0.9847 & 1.3993 & & \\
\hline Wald & $42.41 *$ & $118.84^{*}$ & & \\
\hline
\end{tabular}

ii.Values in brackets indicate the $t$ (only DOLS estimator) and Z statistics.

Panel regression model estimated with CCE, AMG, DOLS and SUR estimators is presented in Table 8. According to regression results both of explanatory variables seem to be significantly related to CAD (coefficient and significance level differ according to estimators). It is also observed that there is positive relationship between savings, ED and CAD. Nevertheless, in the model estimated only by the AMG estimator, the SAVINGS coefficient remains statistically insignificant.

Coefficients vary according to methods. However, the direction of the relationship is the same for all estimators:

- The effect of savings on CAD was estimated as 0.23 (CCE and SUR) and 0.44. 
- The effect of ED on CAD ranges from approximately 0.59 (CCE and AMG) to 1.4 (DOLS). high.

The Wald statistics, which indicate the overall significance of the models, are also quite

Table 9. Estimation Results (by group)

\begin{tabular}{|c|c|c|c|c|c|c|c|c|c|}
\hline \multicolumn{4}{|c|}{ Dependent Variable: CAD } & \multicolumn{6}{|c|}{ Panel Estimators } \\
\hline \multirow{2}{*}{$\begin{array}{l}\text { Countries } \\
\text { Argentina }\end{array}$} & \multirow{2}{*}{$\begin{array}{l}\text { Regressors } \\
\mathrm{S}\end{array}$} & \multicolumn{2}{|r|}{ CCE } & \multicolumn{2}{|c|}{ AMG } & \multicolumn{2}{|l|}{ DOLS } & \multicolumn{2}{|l|}{ SUR } \\
\hline & & 0.2589 & {$[2.73]^{*}$} & 0.1719 & {$[3.08]^{*}$} & 0.8507 & {$[5.5689]^{*}$} & 0.1302 & {$[2.81]^{*}$} \\
\hline & ED & 0.6314 & {$[11.50]^{*}$} & 0.6538 & {$[17.13]^{*}$} & 0.6163 & {$[4.665]^{*}$} & 0.6721 & [22.89]* \\
\hline \multirow[t]{2}{*}{ Egypt } & $\mathrm{S}$ & 0.2378 & {$[2.81]^{*}$} & 0.1859 & {$[2.87]^{*}$} & 0.2293 & {$[1.428]$} & 0.1922 & {$[4.03]^{*}$} \\
\hline & ED & 0.4736 & {$[3.32]^{*}$} & 0.5080 & {$[4.23]^{*}$} & 1.198 & {$[3.615]^{*}$} & 0.5574 & {$[5.98]^{*}$} \\
\hline \multirow[t]{2}{*}{ Pakistan } & $\mathrm{S}$ & 0.4146 & {$[1.90]^{* *}$} & 0.3211 & {$[1.81]^{* * *}$} & 0.0637 & {$[0.422]$} & 0.4887 & {$[2.71]^{*}$} \\
\hline & ED & 0.3231 & [1.49] & 0.4802 & {$[3.45]^{*}$} & 0.9154 & {$[5.733]^{*}$} & 0.3337 & {$[2.29]^{* *}$} \\
\hline \multirow[t]{2}{*}{ Turkey } & $S$ & -0.5440 & {$[-4.41] *$} & -0.3909 & {$[-2.90]^{*}$} & 0.0965 & {$[0.2685]$} & -0.3820 & {$[-2.86]$ * } \\
\hline & $E D$ & 0.7591 & {$[11.12]^{*}$} & 0.7436 & {$[8.11]^{*}$} & 1.502 & {$[4.067]^{*}$} & 0.6720 & {$[7.75]^{*}$} \\
\hline \multirow[t]{2}{*}{ Qatar } & $\mathrm{S}$ & 0.1045 & [0.99] & 0.5607 & {$[9.17]^{*}$} & 1.018 & {$[7.548]^{*}$} & 0.7519 & {$[6.65]^{*}$} \\
\hline & ED & 0.7652 & {$[9.12]^{*}$} & 0.5640 & {$[10.71]^{*}$} & 0.7192 & {$[5.475]^{*}$} & 0.5306 & [4.99]* \\
\hline
\end{tabular}

ii.Values in brackets indicate the tonly DOLS estimator) and Z statistics.

In order to evaluate model estimations in more detail, results on the basis of groups are also shared. Table 9 shows the regression estimation results by groups. According to the results of the analysis; countries.

The external debt increases the CAD in all countries in the fragile group of five

In Turkey, an increase in savings affects the CAD differently; an increase in savings brings with it a decrease in the CAD. CAD.

In the New Fragile Five Countries (except Turkey), the increase in savings increase the

It is possible to explain this unexpected situation which is seen in the New Fragile Five (except Turkey) with the argument put forward by Caldéron. If the correlation between savings and growth is smaller than the correlation with growth and investments, then savings increasing the CAD. So is the GDP-Savings correlation in the New Fragile Five, lower than the GDPInvestment correlations? To clarify this question, the correlation coefficients between the mentioned variables were examined. Correlation tables are presented in Tables 10-11-12.

Table 10. Correlation Coefficient Table (Turkey)

\begin{tabular}{|l|l|l|}
\hline & GDP & Savings \\
\hline GDP & 1.0000 & \\
\hline Savings & 0.0854 & 1.0000 \\
\hline
\end{tabular}

\begin{tabular}{|l|l|l|}
\hline & GDP & Investment \\
\hline GDP & 1.0000 & \\
\hline Investment & 0.5219 & 1.0000 \\
\hline
\end{tabular}

Table 11. Correlation Coefficient Table (The Fragile Five Countries - Turkey excluded)

\begin{tabular}{|l|l|l|}
\hline & GDP & Savings \\
\hline GDP & 1.0000 & \\
\hline Savings & 0.4722 & 1.0000 \\
\hline
\end{tabular}

\begin{tabular}{|l|l|l|}
\hline & GDP & Investment \\
\hline GDP & 1.0000 & \\
\hline Investment & 0.4578 & 1.0000 \\
\hline
\end{tabular}

Table 12. Correlation Coefficient Table (The Fragile Five Countries - Turkey included)

\begin{tabular}{|l|l|l|}
\hline & GDP & Savings \\
\hline GDP & 1.0000 & \\
\hline Savings & 0.4379 & 1.0000 \\
\hline
\end{tabular}

\begin{tabular}{|l|l|l|}
\hline & GDP & Investment \\
\hline GDP & 1.0000 & \\
\hline Investment & 0.4384 & 1.0000 \\
\hline
\end{tabular}


At this stage, correlation coefficients were examined for three different situations. First, in Turkey's GDP-Savings correlation and GDP-Investment correlation has been analyzed (Table 10). Then, both the New Fragile Five Countries - include Turkey (Table 12) and the New Fragile Five Countries - except Turkey (Table 11) were examined. As can be seen from the Table 10; Savings-GDP correlation is smaller than Investment-GDP correlation in Turkey. But the findings do not appear to support the Caldéron argument. But when the results of the panel (Table 8 and Table 12) are evaluated together, it is seen that the argument as argued by Caldéron is valid.

\section{CONCLUSION}

Current account deficit is a closely monitored indicator as a significant signal of future crises. And inadequacy of national savings is regarded as a significant cause behind current account deficit. Purpose of this study is to test the relationship between savings and CAD in the New Fragile Five, which become fragile due to balance of payments disequilibrium. For this purpose, 1994-2019 period annual national savings, current account balance and external debt have been analyzed within the framework of panel data analysis. The model was expanded with the external debt variable to better explain the relationship between savings and current account deficit in the Fragile Five. At the modeling stage of the research focused on the cointegration relationship. Panel cointegration tests with structural breaks based on LM developed by Westerlund (2006) and Westerlund \& Edgerton (2008) were used. Economic growth and investments are included in the analysis as auxiliary indicators.

According to the results of the analysis;

- There is a cointegration relationship between relevant macroeconomic indicators.

- The external debt increases the CAD in the New Fragile Five countries.

- An increase in savings in Turkey -in contrast to the other countries- leads to a decrease in CAD.

- An increase in savings in Argentina, Egypt, Pakistan and Qatar causes an increase in CAD.

This surprising result can be explained by the argument put forward by Caldéron et el. (2000); if the growth-savings correlation remains lower than the growth-investment correlation, an increase in savings may lead to an increase in the CAD. But when the correlations of the related variables are analyzed, a result that does not support the argument of Caldéron is encountered. However, when the panel results are evaluated for all countries that constitute the fragile five, the argument defended by Caldéron is valid. However, the unique economic structures of the countries are very important and taken into consideration in the research; in the New Fragile Five Countries (except Turkey), where savings increase current deficits, the savings-GDP correlation is higher than the investment-GDP correlation. Whereas, in Turkey, where savings reduce current deficits, the savings-GDP correlation is lower than the investment-GDP correlation. These results identified for Turkey, which contrasts with the studies of Caldéron et al. (2000) and Ayla and Küçükkale (2018). This study is contributory to the "Triple Deficit" hypothesis involving few studies on this subject and the results of this study will contribute to the expansion of typology. 


\section{REFERENCES}

ALTUNÖZ, U., (2018). Cari açık bütçe açı̆̆ı ve yatırım-tasarruf açığı bağlamında Türkiye'nin üçüz açık analizi. Maliye Dergisi, Temmuz-Aralık 2018, 175, pp.115-139.

ARISTOVNIK, A., (2006). The determinants excessiveness of current account deficits in Eastern Europe and the former Soviet Union. The William Davidson Institute Working Paper, (827), pp.1-26.

AYLA, D. and KÜÇÜKKALE, Y., (2018). Cari açık ve tasarruf ilişkisi: Caldéron Argümanı bağlamında Türkiye örneği. Atatürk Üniversitesi İktisadi ve İdari Bilimler Dergisi, 32(2), pp.315-334.

BARIŞ, S. and UZAY, N., (2015). Yurtiçi tasarruflar ve ekonomik büyüme arasındaki ilişki: Türkiye örneği. Erciyes Üniversitesi İktisadi ve İdari Bilimler Fakültesi Dergisi, 46, pp.119-151.

BRISSIMIS, S. N., HONDROYIANNIS, G., PAPAZOGLOU, C., TSAVEAS, N. T., and VASARDANI, M. A., (2010). Current account determinants and external sustainability in periods of structural change. Bank of Greece Working Paper, pp.117, 1-38.

BRISSIMIS, S., HONDROYIANNIS, G., PAPAZOGLOU, C., TSAVEAS, N., and VASARDANI, M., (2011). The determinants of current account imbalances in the Euro aArea: a panel estimation approach. Munich Personal Repec Archive, 35362, pp.1-30.

CALDÉRON, C., CHONG, A., and LOAYZA, N., (2000). Determinants of current account deficits in developing countries. Policy Research Working Paper, 2398, pp.1-37.

CALDÉRON, C., CHONG, A., LOAYZA, N., (2002). Determinants of current account deficits in developing countries. Contributions to Macroeconomics, 2(1), pp.1-31.

CALDÉRON, C., CHONG, A., ZANFORLIN, L., (2001). Are African current account deficits different? Stylized facts, transitory shocks and decomposition analysis. IMF Working Paper, 1(4), pp.1-39.

CARRION-I-SILVESTRE, J., CASTRO, T., and LÓPEZ-BAZO, E., (2005). Breaking the panels: an application to the GDP per capita. The Econometrics Journal, (2), pp.159175 .

CHOI, H., MARK, N. C., and SUL, D., (2008). Endogenous discounting, The World saving glut and the U.S. current account. Journal of International Economics, (75), pp.30-53.

CHOWDHURY, K., and SALEH, A.S., (2007). Testing the Keynesian proposition of twin deficits in the presence of trade liberalisation: evidence from Sri Lanka. Department of Economics, University of Wollongong.

ÇIĞDEM, G., (2017). Investigation of the relationship between current account deficit and savings in Mena Economies: an empirical approach. Int. Eco. Res, 2017, 8(3), pp.0106.

ÇIĞDEM, G. and ÜLGEN, G., (2017). Is the inadequacy of national savings the reason of current account deficit? Empirical analysis in Fragile Eight. The Empirical Economics Letters, 16(4), pp.297-310.

EBERHARDT, M. and BOND, S., (2009). Cross-section dependence in nonstationary panel models: a novel estimator. MPRA Paper 17692, University Library of Munich. Available at: http://mpra.ub.uni-muenchen.de/17692/1/MPRA_paper_17692.pdf. 
EBERHARDT, M. and TEAL F., (2010). Productivity analysis in global manufacturing production. Economics Series Working Papers 515, University of Oxford, Department of Economics.

ENGEL, C., and ROGERS, J. H., (2006). The U.S. current account deficit and the expected share of World output. Journal of Monetary Economics, 53, pp.1063-1093.

GENGENBACH, C., URBAIN, J. P., and WESTERLUND, J., (2016). Error correction testing in panels with common stochastic trends. Journal of Applied Econometrics, 31(6), pp.982-1004.

GÜLOGLU, B., TEKIN, R.B., and SARIDOGAN, E., (2012). Economic determinants of technological progress in G7 countries a re-examination. Economic Letters, 116, pp.604-608.

HERRMANN, S., and JOCHEM, A., (2005). Determinants of current account developments in the Central and East European EU member states - consequences for the enlargement of the Euro Area. Deutsche Bundesbank Discussion Paper, 32, pp.1-43.

KAPETANIOS, G., PESARAN H. M., and YAMAGATA, T., (2011). Panels with nonstationary multifactor error with structures. Journal of Econometrics, 160(2), pp.326348.

KARANFIL, M., (2014). Türkiye ekonomisinde tasarruf açı̆̆ı sorunu: zaman serisi analizi. Journal Of Entrepreneurship And Development, 9(2), pp.1-18.

KAYGISIZ, A.D., KAYA, D.G., and KÖSEKAHYAOĞLU, L., (2016). Türkiye'de tasarruf, yatırım, cari açık ve büyüme: 1980-2014 dönemi üzerine bir nedensellik ilişkisi analizi. Çankırı Karatekin Üniversitesi Sosyal Bilimler Enstitüsü Dergisi, 7(1), pp.273-300.

KETENCI, N., (2010). Major determinants of current account in Russia. Transition Studies Review, 17(4), pp.790-806.

KETENCi, N. and UZ, İ., (2009). Determinants of current account in the EU: the relation between internal and external balances. International Conference on Applied Economics, pp.297-306.

LIANG, S., (2012). Determinants of the U.S. current account. International Journal of Social and Human Sciences, 6, pp.297-302.

MADDALA, G.S., TROST, R.P., LI, H., and JOUTZ, F., (1997). Estimation of short-run and long-run elasticities of energy demand from panel data using sharinkage estimators. Journal of Business and Economic Statistics, 15, pp.90-100.

MURTY, K. S., SAILAJA, K., and MULUGETA, D. W., (2013). Macroeconomic determinants of current account deficit in Ethiopia. Excel International Journal of Multidisciplinary Management Studies, 3(1), pp.1-13.

OBSTFELD, M., and ROGOFF, K., (1994). The intertemporal approach to the current account. National Breau Economic Research, (4893), pp.1-75.

O'CONNELL, P., (1998). The overvaluation of purchasing power parity. Journal of International Economics, 44, pp.1-19.

PEDRONI, P., (2001). Purchasing power parity tests in cointegrated panels. The Reviews of Economics and Statistics, 83(4), pp.727-731.

PESARAN, M. H., (2006). Estimation and inference in large heterogeneous panels with a multifactor error structure. Econometrica, 74(4), pp.967-1012. 
PESARAN, M.H., (2007). A Simple panel unit root test in the presence of cross sectional dependence. Journal of Applied Econometrics, 22(2), pp.265-312.

PESARAN, M.H., (2015). Testing weak cross-sectonal dependence in large panels. Econometric Reviews, 34, pp.1089-1117.

PESARAN, M. H. and SMITH R.P., (1995). Estimating long-run relationships from dynamic heterogeneous panels. Journal of Econometrics, 68(1),pp.79-113.

PESARAN, H., ULLAH, A., and YAMAGATA, T., (2008). A bias-adjusted $1 \mathrm{~m}$ test of error crosssection independence. Econometrics Journal, 11, pp.105-127.

PESARAN, M.H., and YAMAGATA, T., (2008). Testing slope homogeneity in large panels. Journal of Econometrics, 142(1), pp.50-93.

SWAMY, P.A.V.B., (1970). Efficient inference in a random coefficient regression model. Econometrica, 38(2), pp.311-323.

TAYLOR, A.M., (2002). A century of current account dynamics. Journal of International Money and Finance, 21(6), pp.725-748.

TAYLOR, M.P., and SARNO, L., (1998). The behavior of real exchange rates during the postBretton Woods period. Journal of International Economics, 46, pp.281-312.

WESTERLUND, J., (2006). Testing for Panel Cointegration with Multiple Structural Breaks. Oxford Bulletin of Economics\&Statistics, 68(1), pp.101-132.

WESTERLUND J., and EDGERTON, D.L., (2008). A simple test for cointegration in dependent panels with structural breaks. Oxford Bulletin of Economics and Statistics, 70(5), pp.665-704.

ZELLNER, A., (1962). An efficient method of estimating seemingly unrelated regressions and tests for aggregation bias. Journal of American Statistical Association, 57(298), pp.348368 . 


\section{NOTES}

${ }^{1}$ For detailed information about the model, see the study of Westerlund and Edgerton (2008): p.672.

21.Argentina, 2.Egypt, 3.Pakistan, 4.Turkey and 5.Qatar. 